\title{
MIR126 Gene
}

National Cancer Institute

\section{Source}

National Cancer Institute. MIR126 Gene. NCI Thesaurus. Code C80753.

This gene is involved in the regulation of gene expression and plays a role in the development of hepatocellular, lung, colon, breast and prostate carcinomas. 